RESEARCH NOTE

\title{
DEVELOPMENT OF THE PHILOMETRIDS PHILOMETRA OVERSTREETI AND PHILOMETROIDES PARALICHTHYDIS IN THE EXPERIMENTALLY INFECTED COPEPOD OITHONA COLCARVA
}

\author{
Timothy P. Bryan ${ }^{1}$, Lam C. Tsoi ${ }^{1,2}$ and Isaure de Buron ${ }^{1}$ \\ ${ }^{1}$ Department of Biology, College of Charleston, 58 Coming St., Charleston, South Carolina 29401, USA; \\ ${ }^{2}$ Current address: Medical University of South Carolina, Department of Bioinformatics, Charleston, South Carolina 29425, USA
}

\begin{abstract}
Philometra overstreeti Moravec et de Buron, 2006 and Philometroides paralichthydis Moravec et de Buron, 2006 are common parasites of the southern flounder, Paralichthys lethostigma Jordan et Gilbert. Because the life cycles of these parasites are unknown, our goal was to assess whether species of copepod commonly found in our estuaries could serve as intermediate hosts for these philometrids. Individuals of five species of copepods were collected and exposed to $\mathrm{L}_{1}$ larvae of each philometrid species. The cyclopoid Oithona colcarva Bowman was the only species to become successfully infected. Successive moulting of philometrid larvae in the haemocoel of the copepods was studied using transmission electron microscopy. At $23^{\circ} \mathrm{C}$ the moult from $\mathrm{L}_{1}$ to $\mathrm{L}_{2}$ was observed for both species as early as $24 \mathrm{~h}$ post exposure to $\mathrm{L}_{1}$ larvae. The moult from $L_{2}$ to $L_{3}$ was initiated within 2 days post exposure and completed by 6-7 days post exposure. Some parasite-induced tissue damage occurred in the copepod but no cellular response against larval philometrids was observed.
\end{abstract}

Philometrids are primarily histozoic nematodes that are exclusively fish parasites as adults. Although fairly common and potentially pathogenic to their hosts, our current knowledge of this group is quite limited (Moravec 2004, 2006). Whereas freshwater species are better understood (e.g., Anderson 2000, Moravec 2006), life cycles of marine philometrid species are rarely studied and only one such marine life cycle has been reported thus far, and so via the experimental infection of copepods (Sakaguchi and Fukuhara 1975). At this time all known life cycles of philometrids involve a copepod as a first intermediate host (Moravec 2006) and all involve copepods becoming infected after ingesting free-living $\mathrm{L}_{1}$ larvae released from the fish-dwelling larvigerous adult. These $\mathrm{L}_{1}$ larvae penetrate the intestinal wall of the copepod following ingestion and reach the haemocoel where they moult twice and develop into $L_{3}$ larvae, which are then infective to the definitive host (e.g., Moravec 2004). The study presented herein focused on identifying the putative intermediate host(s) of two species of brackish-water philometrids, Philometra overstreeti Moravec et de Buron, 2006 and Philometroides paralichthydis Moravec et de Buron, 2006 via experimental infection. Both species of philometrids are commonly found infecting the southern flounder Paralichthys lethostigma Jordan et Gilbert in the estuarine systems of South Carolina (SC), USA (Moravec and de Buron 2006).

Fish were collected by the staff of the SC Department of Natural Resources using electrofishing and trammel netting in the estuaries along the coast of SC $\left(32^{\circ} 24^{\prime} \mathrm{N}\right.$ to $\left.33^{\circ} 24^{\prime} \mathrm{N}\right)$. Within $24 \mathrm{~h}$ upon return to the laboratory fish were dissected

Address for correspondence: I. de Buron, Department of Biology, College of Charleston, 58 Coming St., Charleston SC 29401, USA. Phone: +1-864-953-5848; Fax: +1-864-953-5453;

E-mail:deburoni@cofc.edu and female philometrids were removed from two distinct microhabitats in the fish: $P$. overstreeti from among the teeth of the upper and lower jaw and $P$. paralichthydis from the joints between the bones forming the buccal cavity. Gravid female worms were placed individually in seawater and lanced to release the $L_{1}$ larvae to infect copepods within 1-3 h of fish dissection. Copepods were collected using a $150 \mu \mathrm{m}$ mesh plankton net drawn horizontally within $2 \mathrm{~m}$ of the surface in the Charleston harbour ( $32^{\circ} 45^{\prime} 09^{\prime} \mathrm{N}, 7^{\circ} 53^{\prime} 56^{\prime}$ 'W). Individuals of the following commonly found copepods were collected and sorted according to species: the calanoids Acartia tonsa Dana, Parvocalanus crassirostris (Dahl), and Temora turbinata (Dana); the cyclopoid Oithona colcarva Bowman; and the poecilostomatoid Saphirella tropica Wolfenden. Ten individuals of each species of copepod were then placed in separate $10-\mathrm{ml}$ Petri dishes containing decanted seawater and exposed to over $500 \mathrm{~L}_{1}$ larvae of either one or the other of the two species of philometrid for $24 \mathrm{~h}$ at $23^{\circ} \mathrm{C}$. The experiment was repeated twice. After $24 \mathrm{~h}$, copepods were crushed individually to check for the presence of larval philometrids in the haemocoel. Because only O. colcarva were infected $24 \mathrm{~h}$ post exposure following initial copepod infections, further experiments were pursued only with this species. In short, a total of 50-100 individuals of $O$. colcarva per Petri dish were exposed separately to $\mathrm{L}_{1}$ larvae of each philometrid species as described above. Larvae were removed between $24 \mathrm{~h}$ and $38 \mathrm{~h}$ later to insure a high percent infection. Copepods were maintained at $23^{\circ} \mathrm{C}$ on a cycle of $12 \mathrm{~L}: 12 \mathrm{D}$. The water in the Petri dishes was replaced every other day with freshly collected seawater filtered with a $70 \mu \mathrm{m}$ mesh in order to assure the passage of the algae and protists upon which the copepods feed. Copepods were sub-sampled and crushed regularly every day to determine the time of philometrid larvae moulting. Days post exposure (d.p.e.) were calculated from the time copepods were first placed in contact with philometrid larvae. Because moulting was difficult to see in live animals and because we assumed that it could be mechanically induced by the pressure put on copepods to crush them to release the larvae, we used histology and transmission electron microscopy to confirm the time of moulting. In brief, two to three infected copepods at various d.p.e. as well as uninfected controls were fixed in $2 \%$ glutaraldehyde in $0.1 \mathrm{M}$ cacodylatesucrose buffer, rinsed in buffer, post-fixed in $1 \%$ osmium tetroxide in water, and processed according to classical techniques for Epon embedding. Serial $1 \mu \mathrm{m}$ semithin sections were stained with toluidine blue. Ultrathin sections were stained with uranyl acetate and lead citrate and observed with a JEOL JEM 1210 transmission electron microscope.

Of the initial five copepod species experimentally exposed to the $\mathrm{L}_{1}$ larvae of $P$. overstreeti and $P$. paralichthydis, only individuals of the cyclopoid $O$. colcarva were successfully 

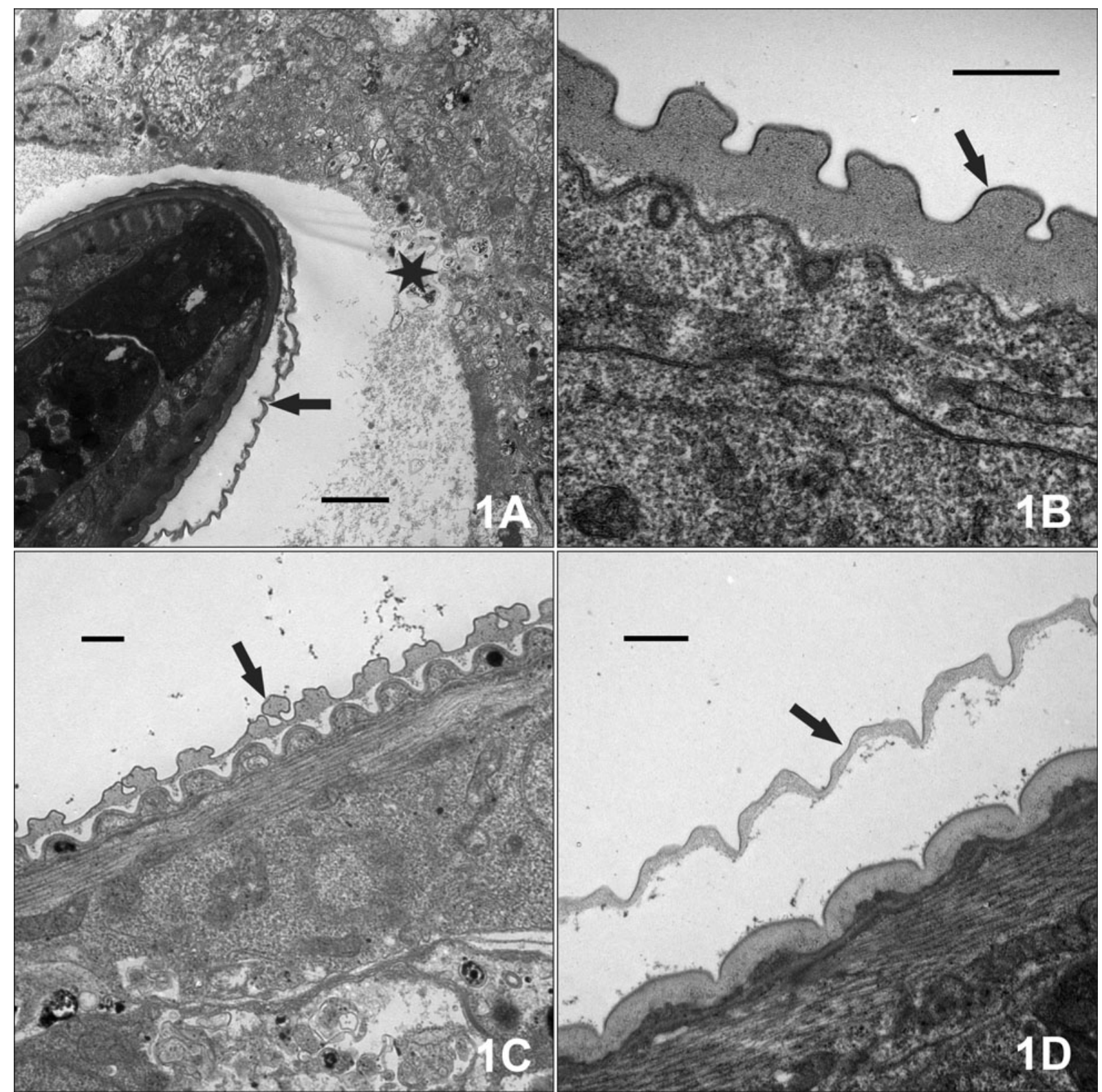

Fig. 1. Transmission electron micrographs of larvae of Philometroides paralichthydis showing the continuous process of moulting in the haemocoel of an individual Oithona colcarva. $\mathbf{A}-\mathrm{L}_{2}$ in $\mathrm{L}_{1}$ moult (arrow) 2 days post exposure (d.p.e.) - see damage of tissues in contact (star); $\mathbf{B}-\mathrm{L}_{3}$ in $\mathrm{L}_{2}$ moult (arrow) 3 d.p.e.; $\mathbf{C}-\mathrm{L}_{3}$ in $\mathrm{L}_{2}$ moult (arrow) 5 d.p.e.; $\mathbf{D}-\mathrm{L}_{3}$ in thin and fully detached $\mathrm{L}_{2}$ moult (arrow) 7 d.p.e. Scale bars: $\mathrm{A}=2 \mu \mathrm{m} ; \mathrm{B}, \mathrm{D}=500 \mathrm{~nm} ; \mathrm{C}=1 \mu \mathrm{m}$.

infected. Within 1 d.p.e., larvae of both philometrid species were seen inside the guts of the copepod. Although most infected copepods harboured one to two philometrid larvae, we also observed higher numbers of larvae in the haemocoel of some copepods, with nine larvae being found in one instance. In both species moulting from $\mathrm{L}_{1}$ to $\mathrm{L}_{2}$ occurred within 2 d.p.e. (Fig. $1 \mathrm{~A}$ ) and a second moult from $\mathrm{L}_{2}$ to $\mathrm{L}_{3}$ was initiated by 3 d.p.e. (Fig. 1B). The moulting process was continuous and showed progressive detachment and thinning of the cuticle (Fig. 1C). In both species the cuticle completely separated from the larvae by 7 d.p.e. (Fig. 1D). All $\mathrm{L}_{3}$ larvae remained encased in the loose $L_{2}$ cuticle for as long as the host copepod could be maintained, which on average was 11 d.p.e. but in one case was 31 d.p.e. Although soft tissues of infected copepods directly in contact with the philometrid larvae were progressively degraded (Fig. 1A), no obvious or overt host cellular defence reaction was observed.

The observation of two successive moults occurring in each species of philometrid within individuals of Oithona colcarva and the repeatability of these experimental infections indicate that this species of copepod is a possible intermediate host for both philometrid species. Successful experimental infection of Paralichthys lethostigma is needed to confirm this conclusion and we are currently attempting to carry out these infections in our laboratory. Support for $O$. colcarva as the natural host for these nematodes comes from the fact that the 
range of this copepod species (Razouls et al. 2008) encompasses the range of the southern flounder, which is found from about Cape Hatteras, North Carolina, through the northern part of the Gulf of Mexico (Froese and Pauly 2008), as well as the fact that no other copepod species examined was capable of being infected. Whether more intermediate hosts occur is a recognized possibility and is unknown at this time. Significantly, O. colcarva is a euryhaline species (Bowman 1975) and its selection as a potential vector available over a broad range of salinities may be a reflection of the fact that throughout their life in the estuarine system, southern flounders perform small-scale migrations up and down the tidal rivers feeding the estuaries (Prentice 1989). In effect, although it is likely that the life cycle of $P$. overstreeti occurs at a higher salinity because of its absence in smaller fish that live higher in the river in low salinity waters, it is possible that infection by $P$. paralichthydis is acquired at lower salinities by youngof-the-year flounders (pers. obs.). Further, although $O$. colcarva populations display a seasonal occurrence in temperate regions (Lonsdale 1981a), it is known to occur in the SC estuarine system throughout the year, with its highest abundance occurring from June through mid-July (Lonsdale and Coull 1977, Knott 1980).

Since development of the larvae of $P$. paralichthydis and $P$. overstreeti requires only about 7 days at $23^{\circ} \mathrm{C}$ in the copepod and because the maximum life span of an individual O. colcarva is known to be only about 53 days at $20^{\circ} \mathrm{C}$ and 39 days at $25^{\circ} \mathrm{C}$ (Lonsdale 1981b), the presence of paratenic hosts in these philometrids' life cycles is highly likely. This contention is supported by the occurrence of infection of both species in large piscivorous flounder, which do not feed upon copepods, and the fact that such transport hosts are a wellknown and important component in the life cycle of numerous other piscine parasites (Morand et al. 1995).

It is important to note that the $\mathrm{L}_{3}$ larvae observed herein remained in the cuticle shed during the second moult, which has also been reported for Philometra ovata by Moravec (1980). It is possible that this conserved cuticle allows the philometrid larvae to evade the copepod immuno-defence system, since no obvious host defence reaction was observed. Significantly, the juveniles of both $P$. paralichthydis and $P$. overstreeti remained very active and thrashed inside the haemocoel of the copepods at all times observed. Whereas this thrashing may have induced at least part of the destruction of tissues in direct contact with the larvae (Fig. 1A), it cannot be discounted that the observed damage may also have been induced biochemically. Although, it is not known if philometrid larvae release excretory-secretory products in their copepod hosts, such a phenomenon is common in nematode larval stages found in vertebrate hosts (Abollo et al. 2001, Lun et al. 2003) and it would not be unexpected to find that such products play a significant role in causing host damage in the copepod. The impacts of infection on the copepod species composition of the estuarine plankton community are unknown at this time.

We particularly thank David M. Knott from the Southeastern Taxonomic Center at SCDNR for his help with the identification of the copepod species and the staff from the Inshore Fisheries Division at SC DNR, in particular William A. Roumillat, for providing the fish. We also want to thank Emma
Arotcharen for her initial work on this project, Carol Moskos from the Medical University of SC for her electron microscopy expertise, and Dr. Vince Connors from the University of SC Upstate for reviewing this paper. This study was funded by grants from the undergraduate research program of the College of Charleston to T.P.B. and L.C.T.

\section{References}

ABollo E., D’Amelio S., PASCUAL S. 2001: Fitness of the marine parasitic nematode Anisakis simplex s.str. in temperate waters of the NE Atlantic. Dis. Aquat. Org. 45: 131-139.

ANDERSON R.C. 2000: Nematode Parasites of Vertebrates: Their Development and Transmission. 2nd ed. CABI Publishing, New York, 650 pp.

BoWMAN T. 1975: Oithona colcarva, n. sp. an American copepod incorrectly known as O. brevicornis (Cyclopoida: Oithonidae). Chesapeake Sci. 16: 134-137.

FROESE R., PAULY D. (Eds.) 2008: FishBase. World Wide Web electronic publication. www.fishbase.org, May 2008

KNOTT D.M. 1980: The zooplankton of the North Edisto River and two artificial saltwater impoundments. M.S. Thesis, College of Charleston, $78 \mathrm{pp}$.

LONSDALE D.J. 1981a: Regulatory role of physical factors and predation for two Chesapeake Bay copepod species. Mar. Ecol. Prog. Ser. 5: 341-351.

LONSDALE D.J. 1981b: Influence of age-specific mortality on the life history of two estuarine copepods. Mar. Ecol. Prog. Ser. 5: 333-340.

LONSDALE D.J., COULL B.C. 1977: Composition and seasonality of zooplankton of North Inlet, South Carolina. Chesapeake Sci. 18: 272-283.

LUN H.M., MAK C.H., KO R.C. 2003: Characterization and cloning of metallo-proteinase in the excretory/secretory products of the infective-stage larva of Trichinella spiralis. Parasitol. Res. 90: 27-37.

MORAND S., ROBERT F., CONNORS V.A. 1995: Complexity in parasite life-cycles: population biology of cestodes in fish. J. Anim. Ecol. 64: 256-264.

MoRAVEC F. 1980: Development of the nematode Philometra ovata (Zeder, 1803) in the copepod intermediate host. Folia Parasitol. 27: 29-37.

MORAVEC F. 2004: Some aspects of the taxonomy and biology of dracunculoid nematodes parasitic in fishes: a review. Folia Parasitol. 51: 1-13.

MorAVEC F. 2006: Dracunculoid and Anguillicoloid Nematodes Parasitic in Vertebrates. Academia, Praha, 636 pp.

MoRAVEC F., de Buron I. 2006: Two new species of philometrid nematodes (Nematoda: Philometridae) from the southern flounder Paralichthys lethostigma in the estuaries of South Carolina, USA. Folia Parasitol. 53: 139-146.

PRENTICE J.A. 1989: Low-temperature tolerance of southern flounder in Texas. Trans. Am. Fish. Soc. 118: 30-35.

Razouls C., De Bovée F., Kouwenberg J., Desreumaux N. 2008: Diversity and Geographic Distribution of Marine Planktonic Copepods. http://copepodes.obs-banyuls.fr/en

SAKAGUCHI S., FUKUHARA O. 1975: Studies on a nematode, Philometra, in the marine benthic fishes. II. Morphology of the larvae and experimental infection to the intermediate host. Bull. Nansei Reg. Fish. Res. Lab. 8: 1-10.

Received 25 February 2008

Accepted 1 September 2008 